R E P O

or

COMATTTEE ON THESIS

THE undersigned, acting as a committee of the Graduate School, have read the accompanying thesis submitted by ... Juliug Serall

for the degree of .......Meter of Science.

They approve it as a thesis meeting the requirements of the Graduate School of the Unirersity of Minnesota, and recommend that it be accepted in partial fulfillment of the requiroments for the degree of Master of Sclence.

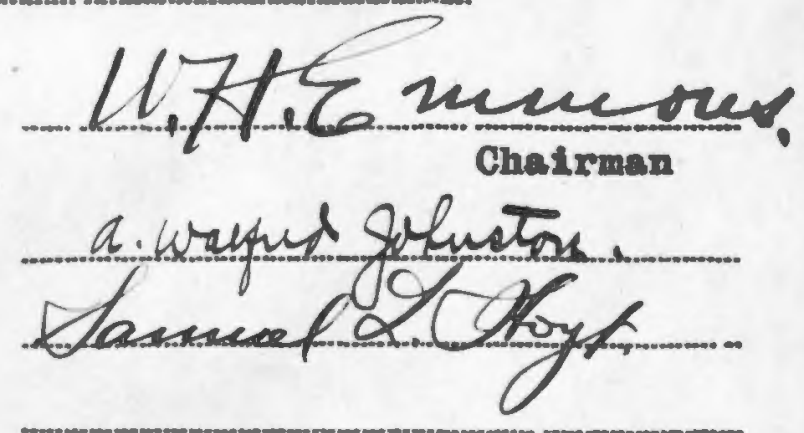




\section{THE ORIGIN AND OCCURRENCE OF CERTAIN} CRYSTALIOGRAPHIC INTERGROWTHS.

A Thesis Submitted to the Faculty of the Graduate Sohool of the University of Minnesota

by

Julıs Segall.

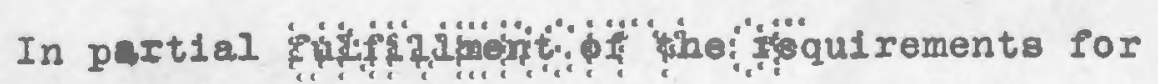

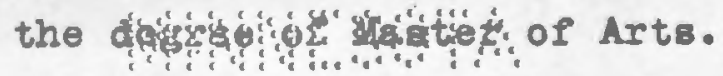
: 


\section{THE ORIGIN AND OCCURRENCE OF CERTAIN}

CRYSTALLOGRAPHIC INTERGROWTHS.

A relationship of minerals which is comonly referred to crystallographic or micrographic intergrowth is a feature of their paragensis. There is no uniform opinIon as to the significance of these intergrowths. Laney ${ }^{1}$ who first recognized them in sulphide ores, believes that the orystallographic intergrowth of bornite and chalcocite of Virgilina is evidence of the contemporaneous origin of these minerals. Gilbert and Pogue ${ }^{2}$ hold that the graphic Intergrowth of borntte and chalcocite of the North Mount

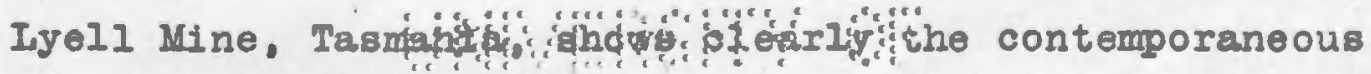

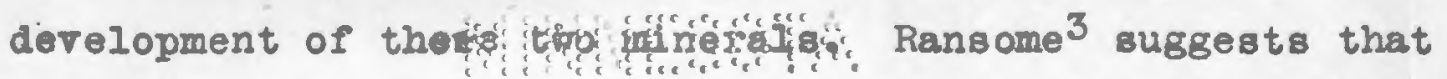
secondary processes mayy would be difficult to distingulah from contemporaneous intergrowths. Rogers ${ }^{4}$ who discovered such intergrowths in 1. Ianey, F. B.. The Relation of.Bornite and Chalcooite in the Copper Ores of the Virgilins District of North CaroIina and Virginia. Econ. Geology, Vol. $6, p .408$.

Graton, I. C. and Jurdoch, J., The Sulphide Ores of Copper; Some results of Mlcroscoplc Study. Trans. A. I. 1. F. Vol. 45, p. 77.

2. Gilbert, C. G. and Pogue, J. G., The Iount Iyell Copper

District of Tasmania. Proc. U. S. Yat'I Muss Vol.45, p.616

W. Ransome, F. I. Copper Doposits near Superior, Ar12. U. S. G. S. Bulietin 540. p. 152 .

4. Rogers, A. I. Secondery Sulphide Enrichment of Copper Ores, with Special Reference to Microscopic Study. Min1ng and Scient1f10 Press. Oct. $31,1914, \mathrm{p} .686$. 
(2)

Butte ores, states that the so-called graphic intergrowths of bornite and chalcocite is but an irregular replacement of bornite by chalcocite.

The assignment of intergrowths of sulphides to contemporaneous solidification of the minerals from solution is undoubtedly due to the resemblance of the peculiar patterns formed by the sulphides to those of quartz and orthoclase in graphic granite. The micropegmatitic intergrowths of these sllicates are supposed to represent contemporaneous separation from solution. Similar struotures marking the final solidification of solutions are exhibited at the eutectic point of a great many alloys.

In the course of this investigation sereral new examples of micrographic intergrowths were discovered, and some eridence was obtained that some of these intergrowthe may be of secondary origin.

The specimens under consideration were examined both megascopically and microscopically. In the mioroscopic examinations polished surfaces were employed and the specimens were studied by reflected light. The minerals were determined by means of physical and chemical tests. 
(3)

Particular care was taken in the identification of bornite, as it had an important bearing on the problem. The appearance of bornite sometime approached that of covellite, and in case of doubt the mineral in question was compared with a known polished surface of covellite.

An interesting series of relations of bornite to chalcocite were found in chalcocite ore from Butte, Mont. The samples were collected by Mr. Lynn Martin from the Leonard shaft at the depths of 1845 and 2200 feet. A megascop1c examination of the specimens from this mine shows that the chief constituent of the ore is massive chalcocite. Distributed thru the chalcocite are grains of bornite varyIng in size up to one elghth of an inch in dlameter. The other recognizable minerals are pyrite, enargite, and quartz. Under the microscope the most notable feature of the polished surface of the specimen from the 2200 foot level is the symmetrical distribution of the chalcocite and bornite. (See Figure 1.) The chalcocite, represented by the light colored lath-shaped flgures, forms triangular areas which are filled by the bornite. The corregponding angles of the triangles are constant thruout the field of observation 
and it seems clear that the triangles are the expression of some definite crystallographic relation. They suggest directions of oleavage or of twinning. Gilbert and Pogue ${ }^{l}$ developed a triangular pattern by etching chalcocite with nitric acid. These investigators refer to the lines limiting these patterns as characteristic cleavage lines. Ray ${ }^{2}$ who obtains a miorophotograph showing a structure similar to Figure 1, concludes that the chalcocite has "purified" along what he terms crystallographic planes.

Graton and Murdoch ${ }^{3}$ obtain minute partings in three directions by etching massive chalcoolte ore from the Bonanza Mine, Alaska. The same results were obtained by them by etching synthetic chalcocite, produced by fusion of copper and sulphur. They also interpret these partings as clearages of the chalcocite. From the foregoing it appears that the patterns produoed by the so-called cleavages along three directions are characteristic of chalcocite.

The first impression gained from Bigure 1 is that the chalcocite has developed along three directlons within 1. Op. cit., p. 1.

2. Ray, J. C. Paragensis of the Ore Jinerals in the Butte District, Mont. Econ. Geol. Vol 9, July 1914, p. 479. 3. Graton, I. C. and Murdoch, J., The Sulphide Ores of Copper; Some Results of $\mathbf{M l}$ croscop1c Study. Trans. A. I. M. F. Vol. 45, . 7. 79. Big8. 27 and 29. 
the bornite; this, however, is improbable, as these three crystallographic directions are assigned to the chalcocite. It seems more probable to suppose that the bornite developed along the existing directions and thus gave rise to the triangular pattern. The transformation from chalcocite to bornite was probably accomplished by metasomatic replacement. The change is suggested by Figure 2. The path of the replacing solutions was a small fracture, indicated by the black strip which extends horizontally thru the photograph, from which the chalcoite was attacked on both sides. Replacement probably began along the minute partings of crystallographic directions. It gradually proceeded, changing the cross barriers of chalcocite to bornite, until the whole mass of the former was entirely replaced by the latter. The dark areas of bornite on both sides of the fracture are assumed to show this complete metasomatic replacement. Where the change had reached an adranced but not completed stage the chalcocite appears in needle-like forms arranged in one direction only. Where the replacement had been only partly completed the crystallographic features were retained in two, or in all three directions. 
(6)

The intimate relation existing between the fractures and replacement along the crystallographlc directions 1s shown more clearly by Figure 3 . In the lower part of this photomlorograph the dark bornite areas within the triangular chalcocite outlines extend up to the black strip representing the fracture. Above the fracture the light gray area of chalcoolte has not been affected. The replacing solutions, coming thru the opening, apparently confined their activity to one side. Figure 4 also represents a case in whlch the activity on one side of the fracture has been greater than on the other. The replaeement, while more advanced in one direction, is not nearly so complete as in the other; the larger area of bornite still includes many needles of chalcoctte.

The relation of replacement to defined openings is clearly 1llustrated by Figures 2,3 , and 4 , and it seems plausible to suppose that these openings may vary in size eren to minute fractures that can not be detected with powerful magnification. Sub-microscoplc partings existing between planes of crystallographic directions undoubtedly allow the access of altering solutions. By such ac- 
cess there may be developed within the chalcocite a orystallographic intergrowth of bornite and chalcocite that has no connection with visible fractures. This feature is 11lustrated by Figure 5 .

The transformation of chalcocite to bornite requires the addition of iron. That the solutions wich affected the alteration carried iron is suggested by the presence of pyrite in some of the frectures from which the bornite exterds in one or both directions. Where found, the pyrite is udually in the form of stringers within the openings, and it is olearly younger than the bornite. The age of pyrits and 1ts relation to openings suggests that the solutions which formed the pyrite probably furnished the iron for the transformation of the copper sulphides.

The bornite that lines the fractures and extends from the openings into the mass of chalcocite is apparently of secondary origin. Consequently it follows that the trlangular pattern produced by the replacement of chalcocite by bornite is also secondary. The shapes of the triangles composing the pattorn may vary in the different parts of a specimen, depending on the orientation of the 
(8)

section to the crystallographic structure of the chalcocite.

In the change from the crystallographic intergrowth of bornite and chalcocite to the massive bornite there is a series of stages in which the bornite assumes various shapes. In the first stages of replaoement the action is chiefly along orystallographio direotions and the chalcocite is broken up into lath-shaped forms. (See Figure 1.) As the process continues these laths of chalcocite become narrower and narrower until they are entirely transformed into bornite. The replacement proceeds at an unequal rate in the three crystallographic directions, and grains of bornite are developed, which while irregular in outline tend to conform with the three direotions. The latter feature is 1llustrated by Figure 5. In the upper left hand part of the photomlerograph the dark patches of bornite(ifarked $A$ ), still retain one or more of the three crystallographic directions. The dark patches of bornite to the right of the central triangular form (marked B) also show a tendency to preserve these directions. The relation of the regular to the irregular intergrowths 1s 
suggested by Figure 6 . In the lower part of the photomicrograph the irregular figurea, (marked $\boldsymbol{A}$ ) appear to be the continuations of the upper triangular forms. To the right, (marked B) are the characteristic patches of bornite as thəy appear when a number of the smaller irregular forms are merged into one. This feature, which is more clearly expeessed in Figure 7, is by far the more conmon of the two. As with the regular triangular forms, the irregular ones are in part at least modified by the orientation of the specimen with reference to 1 ts crystallographic directions. Since the bornite which forms part of the intergrowth is secondary it is evident that the pattern developed by ine intergrowth of bornite and chalcocite is also secondary. The occurrence of another intergrowth of bornite and chalcocite was found in a sample furnished by the U. S. Nat'l. Museum. The specimen was labelled Silver Copper Ore, Bevelheymer Mine, Peavine District, Washoe Co., Nerada. Most of the sample is covered with a thin coating of chrysocolla. A fresh surface exhibits chalcocite of exceptionally brilliant luster. In addition to these two minerals the microsoopic examination of the unetched polished sur- 
face reveals the presence of bornite which constitutes about $5 \%$ of the speoimen. The chalcocite appears silvery white and the bornite has the characteristic lavender color. The chrysocolla has a dark green color and is largely confined to the fractures. The relation of chalcocite to bornite is illustrated in Figure 8. The bornite, the darker of the two main constituents, has the characteristic branching form assumed to be due to the orystallographic intergrowth of the bornite and chalcocite. Similar to the bornite in Figure 6, the small irregular forms are seen to merge into larger massive patches. The lack of a clearly defined orystallographic arrangement in this specimen prohibits conclusive statements as to the origin of this intergrowth.

The district from which this specimen was obtained produses some gold and silver. Very little is known of the geology of the Peavine district. It is known, however, that the veins in which the ore is found are in granites and schists. This information was kindly furnished by Mr. R. W. Fulton, of Reno, Nevada.

The intergrowths of metall10 sulphides that have 
been described heretofore are all of copper minerals. It is therefore interesting to note an intergrowth of galena and tetrahedrite. The specimen exhibiting this occurrenoe was obtained from the Ward Natural Science eatablishment, and was labelled Tetrahedrite, Kristeid, Norway. The sample is composed chiefly of quartz, with which is associated a green schistose mineral, probably chlorite. Next in abundance is tetrahedrite, which occurs as massive patches and small grains in the quartz. Chalcopyrite and a few grains of pyrite complete the 11st of minerals that can be recognized with the ald of a hand lens. A ilcroscopic examination of the polished surface reveals the presence of galena. The striking feature of the specimen is the intimate intergrowth of the galena and tetrahedrite. The galena, represented by the white mineral in Figure 9, has the appearance of a sponge, the openings of which are filled with little dark particles of tetrahedrite. Along the contact of the two minerals the balena fingers into the tetrahedrite. At the base the galena forms an irregular contact with chalcopyrite. Since there is no arailable information as to the origin of the ore it is not adrisable 
to draw any conclusions as to the mode of formation of the Intergrowths.

Other intergrowths of galena and tetrahedrite are represented in Figures 10 and 11 . Both of these are photomicrographs of a sample from the Elkhorn Mine, Elkhorn District, Jefferson Co., Mont., donated by the U. S. Nat'l Museum. The specimen is composed of quartz, tetrahodrite, gelena, sphalerite, and pyrite. The galene and tetrahedrite are the ohief metallic sulphides; under the microscope the former appears silvery white and the latter light gray. The contact between the two minerals is at some places well defined, but at others very irregular in outine. When 1rregular, the forms assumed by the galena resemble those of the characteristic branching intergrowths. These 1rregular patterns, as far as examined, are always confined to the contacts, and it appears that they are the result of an uneven gradation from one to the other. Weed ${ }^{l}$ in his paper on the Fikhorn mine concludes that the ores have been formed by ascending waters, by replacement of the country rock. To find ore of such pattern replacing 1. Woed, W. H., Geology and Ore Deposits of the Hikhorn Mining District, Jefferson Co., Mont., 2lst Ann. Rept. U. S. G. S. Part 2. D. 496. 
limestone was unexpected, since ordinarily such structures are assumd to represent free crystal growth. Bastin finds similar irregular borders between galena and polybasito. He concludes that galena was replaced by polybasIte with the development of a very "ragged" boundary. If it were assumed that some of the tetrahedrite of the Elkhorn mine were secondary; the irregular distribution of the galena at the contact could be interpreted as an irregular replacement of galena by tetrahedrite.

From the relations presented in the previous pages it is inferred that intergrowth of sulphides may be formed by secondary processes. These intergrowths may have a close resemblance to what are known as contemporaneous intergrowths. Since the exact nature of the replacing solutions is not known, no inferences can be drawn as to whether the solutions were descending or ascending. The writer is much indebted to Dr. W. H. Bmmons for his helpful critiolsmg of this paper.

1. Bastin, E. S., Yetasomatiam in Downward Sulphide Enrichment. Econ. Gool., Vol, 8, D. 56, 1913.

Geological Laboratory.

University of Minnesota. 

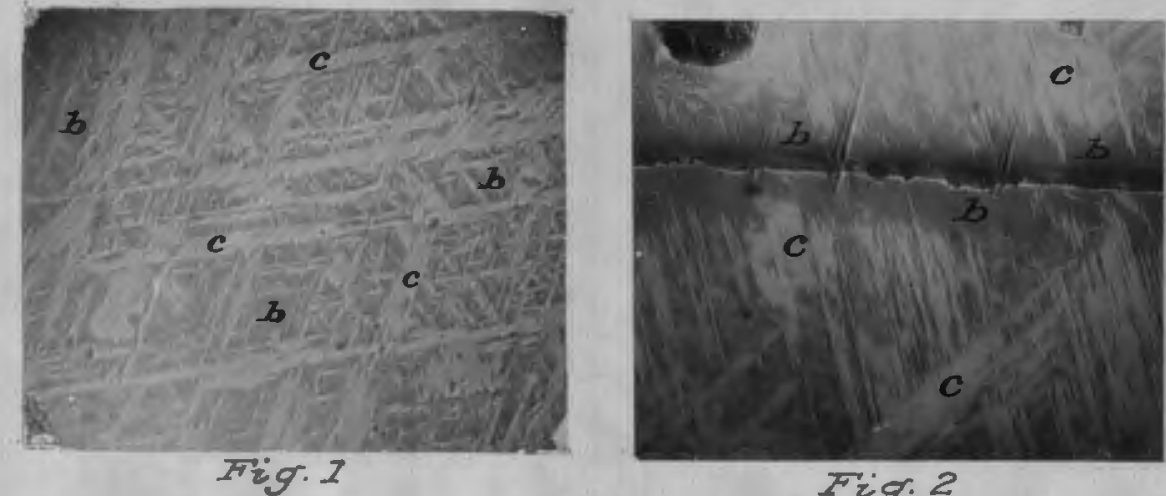

Fig. 2

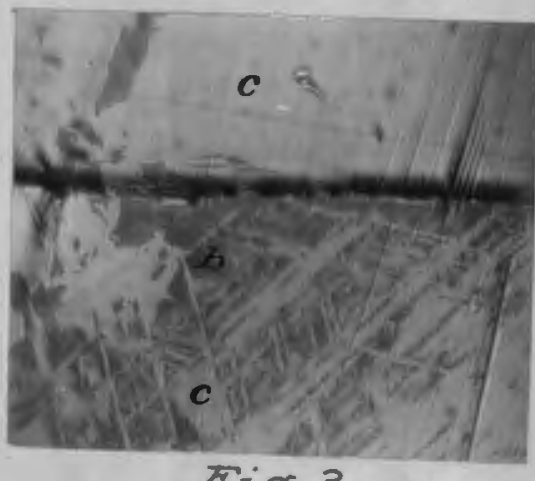

Fig. 3
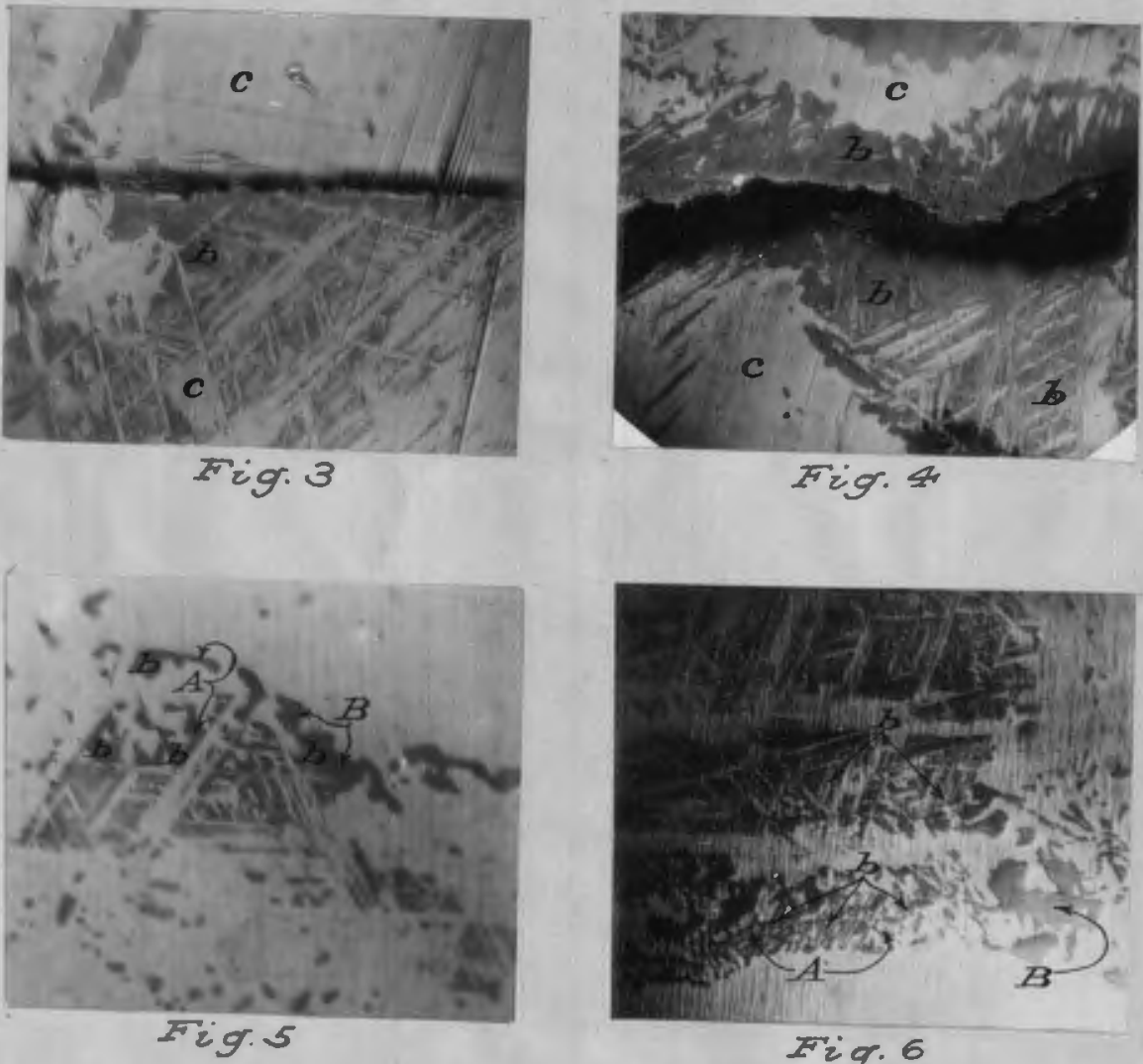

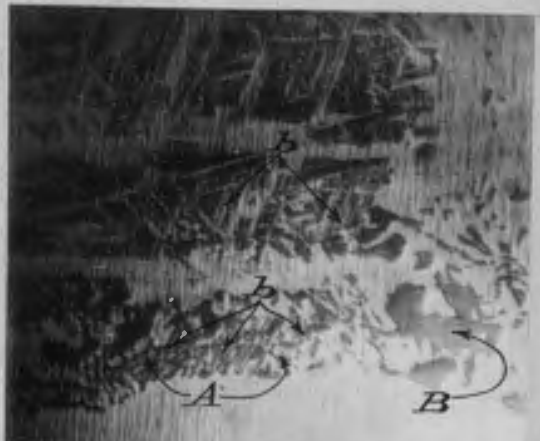

Fig. 6 


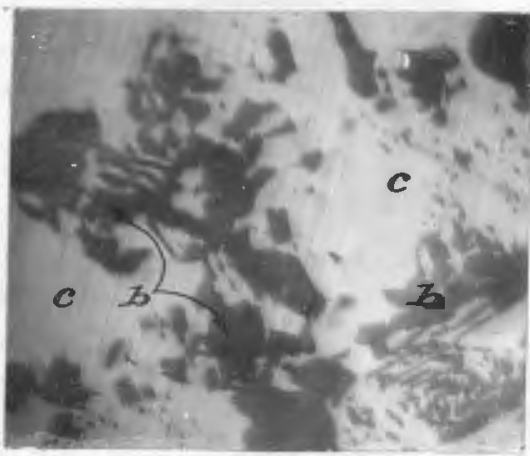

Fig. 7

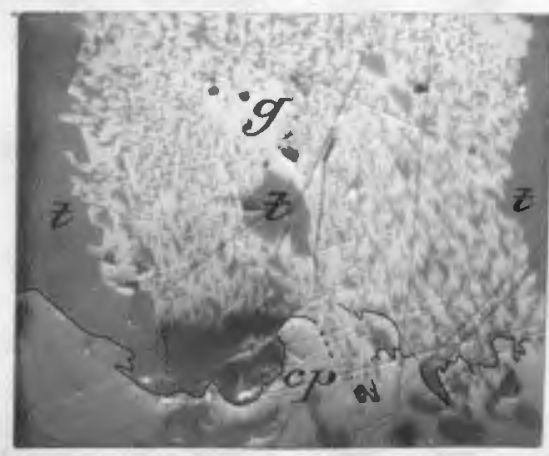

Fig. 9
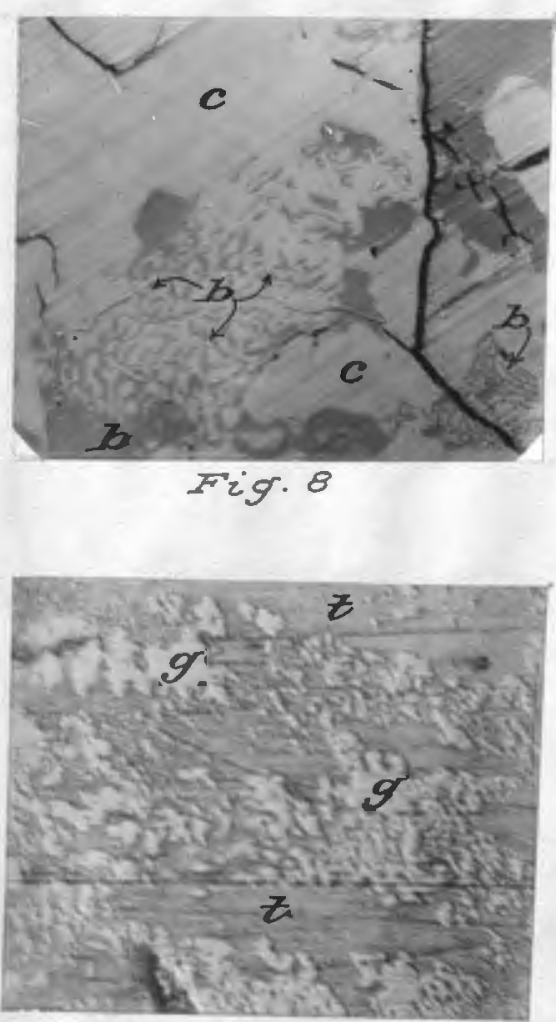

Frig. 10

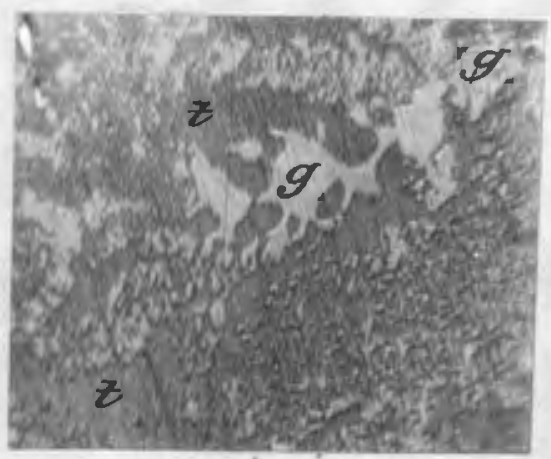

점. II 
Figure 1. Leonard Mine. Butte, Mont.

Crystallographic intergrow th of chalcocite (c) and boralte (b). The orystallographio directlons are assigned to the chalcoc1te. The bornite presurably developed along the existing directions thus giving rise to the triangular patterns.

Magniflcation: $x 700$ (approx)

Figure 3. Leonard Mine, Butte, Mont.

Illustrateg relation between fracturs and replacement along crystallographio directions. In the lowar half of the photomicrograph the triangular pattern extends from the fracture downward.

Magnification: x 350 (approx)

\section{Figure 5. Leonard Mine, Butte, Mont.}

Illustrates the tendency of the massive bornite (b) to develop along the three orystallographio directions.

Magnification: x 700 (approx)
Figure 2. Leonard line, Butte, Mont.

Relation of replacement to opes fractures. The dark areas of bornite (b) on both sides of the blaok strip representing the fracture, are as sumdd to show the replacement of chalcoolte (o) by bornite.

Magniflcat1on: $x 400$ (approx)

Figure 4. Leonard Mine, Butte, Mont.

This photomicrograph shows that the replecercent of bornite (b) by chalcocite (c) has been greater below the fracture than above 1 t.

Magnification: $\times \mathbf{3 5 0}$ (approx)

Figure 6. Le snard Mine, But te, Mont.

Suggests that the irregular forms of bornite (bf in the lower part of the photomicrograph are the continuations of the regular triangular forme of the upper part.

Magnification: $x 350$ (approx) 
Figure 7. Leonard Mine. Butte, Mont.

Characteristic patches of bornite (b) as they appear when a number of smaller irregular forms are merged into one.

Magnification: $x 700$ (approx)

Figure 9. Kristeid, Norway.

Intergrowth of galena ( $g$ ) and tetrahedrite $(t)$. At the base of the galena It forms an irregular contact with chalcopyrite (cp).

Magnifioation: $\times 700$ (approx)
Figure 8. Bevelheymer Mine, Washoe Co., Ner.

Typical intergrowth of bornite (b) and ohalcocite (c).

Magnification: x 250 (approx)
Figures 10 \& 11 . Blkhorn Mine, Jefferson Co., Nev.

Galena ( $g$ ) and tetrahedrite $(t)$ forming patterns which resemble characteristic branching intergrowtho.

Magnification: $x 700$ (approx) 